\title{
THE EFFECT OF CATION EXCHANGE RESIN TREATMENT OF GRAPE MUST ON THE CHEMICAL AND SENSORY CHARACTERISTICS OF BASE WINES FOR SPARKLING WINE
}

\section{EFEITO DO TRATAMENTO COM RESINA DE TROCA CATIÓNICA NO MOSTO DE UVA SOBRE AS CARACTERÍSTICAS QUÍMICAS E SENSORIAIS DOS VINHOS BASE PARA ESPUMANTE}

\author{
Bruno Cisilotto, ${ }^{1,2 *}$, Simone Bertazzo Rossato ${ }^{1}$, Evandro Ficagna ${ }^{1}$, Luísa Carolina Wetzstein ${ }^{1}$, Angelo Gava ${ }^{1}$, \\ Gisele Mion Gugel $^{1}$, Ana Paula Longaray Delamare ${ }^{2}$, Sergio Echeverrigaray ${ }^{2}$
}

${ }^{1}$ Federal Institute of Education, Science and Technology of Rio Grande do Sul-Bento Gonçalves Campus, Brazil.

${ }^{2}$ Institute of Biotechnology, University of Caxias do Sul, 95001-970 Caxias do Sul, RS, Brazil.

* Corresponding author: Tel: +55(54)981141369, email: bruno.cisilotto@bento.ifrs.edu.br

(Received 10.08.2019. Accepted 29.10.2019)

\section{SUMMARY}

Ion exchange resins are polymers with high physical and chemical stability, which, upon activation, acquire positive charge (H+) ions which interchange with existing cations during musts or wines treatment. The chemical composition of the grape must, and wines are highly affected by said modifications. This study aimed to evaluate the impact of the cationic resin treatments on the physicochemical and organoleptic characteristics of base white wines for sparkling wine production. Thus for, Chardonnay must was exposed to a cation exchange resin specific for oenological usage, and fermented to obtain wines. Resulting wines included an untreated control sample with $\mathrm{pH} 3.15$ and treated samples with pH 3.08, 3.02 and 2.97. Physicochemical and volatile compounds analyses as well as quantitative sensory evaluations were conducted. The results showed that, on the scenarios tested, treatments with cationic resins before fermentation resulted in wine with higher oxidative stability, with significative variation on the concentration of several volatile compounds that influenced organoleptic perceptions.

\section{RESUMO}

As resinas de troca iónica são polímeros com alta estabilidade física e química, que, após a ativação, adquirem íons de carga positiva $\left(\mathrm{H}^{+}\right)$que se intercambiam com cátions existentes nos mostos ou vinhos durante o tratamento. A composição química dos mostos e dos vinhos são altamente afetadas por estas modificações. O objetivo deste estudo foi avaliar o impacto da técnica acima mencionada sobre as características químicas e organolépticas dos vinhos brancos base para espumantes. Para tanto, mosto Chardonnay foi exposto a resina de troca cationica para uso enológico, e fermentado para obtenção de vinhos. Os tratamentos incluíram um controle não tratado com pH 3,15 e amostras tratadas com pH modificado para 3,08, 3,02 e 2,97. Foram realizadas análises físico-químicas, medições de cor e compostos voláteis, bem como uma análise sensorial quantitativa. Este estudo mostrou que, nos cenários testados, os tratamentos com resinas catiônicas antes da fermentação resultaram em vinhos com maior estabilidade oxidativa, variação significativa na concentração de diversos compostos voláteis, influenciando as percepções organolépticas.

Key words: wine, cation exchange resin, total acidity, $\mathrm{pH}$, aroma compounds, sensory characteristics.

Palavras-chave: vinho, resina de troca catiônica, acidez total, $\mathrm{pH}$, compostos do aroma, características sensoriais.

\section{INTRODUCTION}

The acidity of grape must and wines are currently controlled for several reasons, mainly to guarantee gustatory balance and increase stability (Blouin and Peynaud, 2006). Techniques of $\mathrm{pH}$ and acidity control, such as qualitative separation of the must during pressing phase, addition of organic acids,

91

This is an Open Access article distributed under the terms of the Creative Commons Attribution License (http://creativecommons.org/licenses/by/4.0), which permits unrestricted use, distribution, and reproduction in any medium, provided the original work is properly cited. 
control of malolactic fermentation and ion exchange resins usage have been studied, tested and discussed (Togores, 2018).

Grape must $\mathrm{pH}$ is considered an important indicator of the wine quality. On white wines intended for the production of sparkling wines, low $\mathrm{pH}$ values are considered to increase freshness, vivacity, and brightness by interfering with redox reactions. Moreover, low $\mathrm{pH}$ values also increase the physical stability and fining of base wines, improving clarification (Moreno and Peinado, 2012).

Cationic resins for oenological purpose directed to increase wine acidity have become a technical option since 2012, when the International Organization of Vine and Wine (OIV) foreseen their usage in grape must and wines to increase of the real and total acidity, resulting in $\mathrm{pH}$ reduction, tartaric acid stabilization, and wine durability (OIV, 2018).

Oenological ion exchange resins are typically constituted by a matrix of cross-linked polystyrene and divinylbenzene. These materials are referred as resins due to the tridimensional porous matrix that support the "exchanging" groups. The resins are obtained by condensation and polymerization, resulting in a polystyrene matrix with high thermoplastic and physical stability, commercialized as 0.3 to $1.2 \mathrm{~mm}$ microspheres (Mira et al., 2004, 2006). Upon activation with $\mathrm{H}+$ ions by acid mineral washing (typically a sulfuric acid solution), the resins act directly, exchanging the $\mathrm{H}+$ ions with cations, mainly $\mathrm{K}+$ and $\mathrm{Ca}+$ present in the grape must or wine. This ionic stoichiometric exchange liberates causes a decrease in $\mathrm{pH}$ and an increase in total acidity (AEB-group, 2013).

Although licensed for winemaking since 2012, the scientific information about the effect of cationic resins treatment of grape musts or the resulting wines is scarce. Some works have been done on red and white wines (Mira et al., 2004; Bruijn et al., 2009; Lasanta et al., 2013; Cabrita et al., 2014; Ibeas et al., 2015) showing important effect on several physicochemical characteristics of wines, but there are not reports on the treatment of grape must for the production of base wines for sparkling wines production, a class of white wines with very peculiar characteristics such as higher acidity, lower alcohol content and lower aromatic intensity.

Total acidity, $\mathrm{pH}$ and volatile acidity are a constant concern of oenologists in the production of wines, especially the base wines intended for sparkling wines. The main reason to such interest is the sensory influence of acidity on final products. Indeed, in professional sensory analysis, alcohol strength, residual sugar, total acidity, $\mathrm{pH}$ and volatile acidity are considered extremely relevant from both gustatory and aromatic characteristics (Ribéreau-Gayon et al., 2007), but their specific effect is still controversial. Despite the consensus on the influence of $\mathrm{pH}$ and acidity on the aroma compounds of wines, few studies show a clear relation between these factors. Lambrechts and Pretorious (2000), among other authors, pointed out that esters produced during alcoholic fermentation are responsible for fruity and floral aromas of wines, some of which are the most important aromatic attributes of white wines. Liu et al. (2015) showed significant differences of yeast response to must $\mathrm{pH}$, and an increase of acetic acid production on lower $\mathrm{pH}$. Esters are produced by enzymatic and chemical esterification, and the acid catalyzed esterification is modified under lower $\mathrm{pH}$ (Marais, 1978; Edwards et al., 1985). However, conflicting results were reported by Patrianakou and Roussis (2013) who pointed the effects of lower $\mathrm{pH}$ on $\mathrm{Fe}$ II ions kidnapping, and the consequent reduction of several esters during wine storage.

The number of cations present in the musts may have a significant influence on fermentations, and consequently in the final aromatic composition of the wine. According to Walker (2004), metal ions may impact on yeast growth and enzymatic activities during fermentation, influencing various parameters such as the conversion rate of sugar to ethanol, yeast biomass production, cell viability and stress tolerance, foam production and yeast flocculation, among others. Moreover, many cations act as cofactors for enzymes and their availability can influence the production of several metabolites.

Additionally, to classical chemical analysis and volatile compounds and color evaluation, a sensory analysis is valuable to support the physical and chemical analyses, through which is possible to verify any connection from visual to olfactory and gustatory evaluations detected during tasting. According to Bailetti et al. (2019), the descriptive analysis (DA) is the most well-known and widely used method of sensory analysis, in which a trained panel is used to identify qualitative and quantitative sensory characteristics of a product and to punctuate their intensities of a set of attributes. Thus, descriptive analysis still stands as the most comprehensive, flexible and useful sensory method, providing detailed information of a given product (Murray et al., 2001).

In this context, the present work aimed to evaluate the physicochemical characteristics, the volatile composition, and the organoleptic attributes of base wines for sparkling wines production obtained from 
'Chardonnay' musts treated with a commercial cation exchange resin. These results will help oenologists to decide pre-fermentative treatments to obtain a desired product.

\section{MATERIAL AND METHODS}

\section{Grape must}

For the experiment, juice of the variety 'Chardonnay' was obtained by pressing the whole clusters with a pneumatic press PPC 9 (Enoveneta SPA, Italy). After extraction, the juice was treated in the following order: enzymatic treatment with pectinase ZIMOPEC PML ( $3 \mathrm{ml} / \mathrm{hL}$ ) (Perdomini-IOC SpA, Italy), addition of sulfur dioxide (50 mg/L SO2), and two hours after the enzyme addition, the juice was clarified with silica Xiles $40(70 \mathrm{ml} / \mathrm{hL})$ (Perdomini-IOC SPA, Italy) and gelatin Gecoll $(10 \mathrm{~g} / \mathrm{hL})$ (LAFFORT, France). Finally, the juice was cooled to $12{ }^{\circ} \mathrm{C}$ for static decantation. After 10 hours the lees were separated (debourbage), and the juices were divided into $5.5 \mathrm{~L}$ volumes for resin treatment.

\section{Ion exchange resin}

The cation exchange resins ( $\mathrm{pH}-\mathrm{Stab})$ and the sulfuric acid activator (ACID + ) used in the present study were acquired from AEB Latin American Biochemistry S.A. (Brazil). The cationic resin (pH$\mathrm{Stab}$ ) is a styrene-divinylbenzene copolymer matrix with sulfonic functional groups, commercialized as microbeads with 0.3 to $1.2 \mathrm{~mm}$. According with the manufacturer, a gram of the resin can interchange 1.4 meq of $\mathrm{H}^{+}$. The doses, application mode, washing procedure and resin regeneration followed the manufacturer's recommendation.

\section{Ion exchange system and experiments}

To perform the ionic exchange between the resins and the juice on a pilot scale, an experimental glass device was developed in cylindrical format, with volumetric capacity of $600 \mathrm{~mL}$ with a Teflon valve, and a porous disc filter type that retains the resin. The juice was passed, and refluxed by the resin column, as many times to obtain the desired $\mathrm{pH}$ reduction. When the must attained the desired $\mathrm{pH}$ it was separated into a container with a volume of $4.4 \mathrm{~L}$ for fermentation. The container volumes were all adjusted by weight with a precision scale. All treatments were made in triplicate.

Subsequently, all samples were submitted to controlled alcoholic fermentation with selected yeast Saccharomyces cerevisiae $(20 \mathrm{~g} / \mathrm{hL})$ Zimaflore X5 (Laffort, France). After 48 hours of fermentation, nutrient Nutristart $30 \mathrm{~g} / \mathrm{hL}$, containing diammonium phosphate, yeast autolysate and thiamine (Laffort, Bordeaux, France), and $15 \mathrm{~g} / \mathrm{hL}$ of Microcol Alpha bentonite (Laffort, France) were added, in order to reduce the risk of stuck fermentation and a to clarify the wine, respectively. After fermentation the wines were subjected to tartaric stabilization (15 days at $0^{\circ} \mathrm{C}$ ), and then bottled and stored at $18^{\circ} \mathrm{C}$ for subsequent analyzes. The treatments comprised of a control sample with $\mathrm{pH} 3.15$, named ST (Standard or Control Treatment), and treated samples with $\mathrm{pH} 3.08$ (TR1), $\mathrm{pH} 3.02$ (TR2) and $\mathrm{pH} 2.97$ (TR3). It is important to emphasize that this is within the $\mathrm{pH}$ used in Brazilian base wines for sparkling production. Given five months after the end of the alcoholic fermentation, the wines were analyzed for their physicochemical characteristics, volatile compounds, and sensory analysis. Moreover, color evolution was monitored during nine months with three months intervals.

\section{Physicochemical analyses}

Alcohol strength (ethanol) was determined by distillation and measurement of the distillate density at $20^{\circ} \mathrm{C}$ in hydrostatic balance (Gibertini, Italy). The alcohol was expressed by volume-volume percentage $(\% \mathrm{v} / \mathrm{v})$. The total dry extract was obtained by the densimetric method using hydrostatic balance (Gibertini, Italy), and reducing substances were measured by Fehling test (AOAC, 1995).

The determination of $\mathrm{pH}$ were performed with a benchtop $\mathrm{pH}$ meter MPA210 (Tecnopon, Brazil) (MAPA, 2013), and total acidity was determined by neutralization of titratable acids using a $\mathrm{NaOH}$ solution (Portaria $\left.n^{\circ} 76 / 1986,1986\right)$. The levels of tartaric acid were evaluated by Wineflow enzymatic kit (Gibertini, Italy). The separation of the volatile acids occurred by steam distillation in Super DEE (Gibertini, Italy) and quantified by titration (Portaria $\left.n^{\circ} 76 / 1986\right)$. Volatile acidity was expressed as $\mathrm{g} / \mathrm{L}$ of acetic acid.

Total phenolic compounds was determined by the Folin-Ciocalteau colorimetric method (Rockenbach et $a l ., 2008)$, and the results were expressed as $\mathrm{mg} / \mathrm{L}$ of gallic acid. Total polyphenols index was determined by absorbance at $280 \mathrm{~nm}$ using an UV/VIS T92 spectrophotometer (PG Instruments, England), according with Ribéreau-Gayon et al. (2007), and free and total sulfur dioxide were quantified using an automatic titrator (Quick, Gibertini Italy). The two parameters were expressed in $\mathrm{mg} / \mathrm{L}$ of sulfur dioxide.

Color intensity of wines was determined by absorbance at $420 \mathrm{~nm}$, and expressed as optical density units (Ribéreau-Gayon et al., 2007). The chromatic characteristics of wines were determined 
with a KONICA MINOLTA colorimeter CR-400 (Tokyo, Japan). The measured parameters were: $\mathrm{L}^{*}$ which represents lightness $\left(\mathrm{L}^{*}=0\right.$ being black and $\mathrm{L}^{*}=100$ being white); $\mathrm{a}^{*}$ and $\mathrm{b}^{*}$ being coordinates of colors responsible for the chromaticity $\left(+a^{*}\right.$ being red and $-a^{*}$ being green, $+b^{*}$ being yellow and $-b^{*}$ being blue), coordinates of CIELab color space, the value of chroma $C^{*}=\left(a^{*^{2}}+b^{*^{2}}\right) 1 / 2$ and hue angle $h^{*}$ $=\operatorname{tg}-1\left(\mathrm{~b}^{*} / \mathrm{a}^{*}\right)$. Data was transmitted through a computer with CR 400 Utility software.

\section{Analysis of volatile compounds}

Determinations of ethanal, ethyl acetate, 1-propanol, 2-methyl-1-propanol, 2-methyl-1-butanol and 3methyl-1-butanol content were performed simultaneously as well as those of the fatty acid content, esters, volatile acids, acetates and 2phenylethanol. All determinations were performed by gas chromatography with flame ionization detector (GC-FID), according to the procedure described by Webber et al. (2014). Chromatographic analyses were conducted in a Agilent Plus 6890 series chromatograph (Santa Clara, CA, USA), with a capillary column HP Innowax $(30 \mathrm{~m} \times 0.25 \mathrm{~mm} \times$ $0.25 \mu \mathrm{m})$. The compounds were identified by comparison of their retention times with authentic standards from Sigma-Aldrich (St Louis, USA), and their concentration determined with a calibration curve prepared for each standard with seven concentration values. The evaluations were conducted in triplicate, and the results were expressed in $\mathrm{mg} / \mathrm{L}$.

\section{Sensory analysis}

Sensory analysis occurred five months after the end of the wine fermentation. It was attended by 13 experienced oenologists in sparkling wines tasting, who act in the official Brazilian wine sector panel. The tasters were not informed about the experiment to avoid tendencies. The quantitative descriptive analysis method (Quantitative Descriptive Analysis QDA) followed the standards of ABNT NBR ISO 13299 (2017). Briefly, the attributes and definitions of the references used in the sensory analysis were predefined with the tasting participants, and included: color intensity; white fruits, floral, citric fruits, and herbaceous aroma; acidity and bitterness. The samples were tasted in insulated booths under artificial lighting with white led lamps. The wines were presented with a randomized block design in 40 $\mathrm{mL}$ aliquots in ISO glass, encoded with three digits. Three repetitions (triplicates) were performed with a 15 minute interval between each section (four wines in each section). The wine tasting temperature was controlled at $12{ }^{\circ} \mathrm{C}$. The intensity of each attribute was rated using a $10 \mathrm{~cm}$ unstructured line scale labeled "little" at the left end and "high" at the right end. Data were collected and analyzed manually by measurement of the lines as recommended by Dutcosky (2007).

\section{Statistical analysis}

The results obtained in the physicochemical and sensory analyses were submitted to an analysis of variance (two-way ANOVA) followed by a mean comparison by the Tukey test at $95 \%$ probability $(p<0.05)$. The results of the sensory analysis were presented in a radar chart. Statistical analyses were achieved by Graphpad Prism ${ }^{\circledR}$, ASSISTAT and Microsoft Excel software.

\section{RESULTS AND DISCUSSION}

Physicochemical characteristics of wines obtained from musts treated by cation exchange resins are shown in Table I. As expected, total acidity was higher on wines obtained from treated musts (Table I) and showed a significant negative correlation with $\mathrm{pH}$ $(\mathrm{r}=-0.9736)$. Although non-significant tartaric acid concentration showed a direct relation with resin treatment intensity as verifying by the high negative correlation between $\mathrm{pH}$ and tartaric acid $(\mathrm{r}=-0.8322)$ Moreover, a positive correlation between total acidity and tartaric acid $(\mathrm{r}=0.364)$ was also evident. The relations observed between $\mathrm{pH}$, total acidity and tartaric acid concentration are the result of the exchange of hydrogen ions of activated resin with the cations of must salts, mainly potassium and calcium tartrate, releasing tartaric acid. This exchange results in a reduction of $\mathrm{pH}$ and an increase in total acidity (AEB-group, 2013). Mira et al. (2006), Cabrita et al. (2014), Ibeas et al. (2015), and Ponce et al. (2018) showed that the treatment of red and white wines with cation exchange resin results in lower $\mathrm{pH}$, and higher total acidity. Ponce et al. (2018) evaluated ion exchange resins applied in wines with several varieties of white and red grapes, on a laboratory and industrial scale, and showed that a significant reduction of the concentrations of $\mathrm{Ca}, \mathrm{K}, \mathrm{Na}, \mathrm{Mg}, \mathrm{Cu}$, $\mathrm{Mn}, \mathrm{Fe}$ and $\mathrm{Zn}$ after treatment with resins. Similar results were obtained by Palacios et al. (2001) after the passage of sherry wines by the resin, and Tamasi et al. (2018) using two types of resin on sweet and dessert wines. Moreover, several authors (Cabrita et al., 2014, Ibeas et al., 2015, Ponce et al., 2018) pointed out that the reduction of cations concentration after cationic resin-treated wines resulted in higher tartaric stability by an increase of tartaric acid and a consequent reduction on tartaric salts. 
TABLE I

Physicochemical characteristics of wines obtained from musts treated by cation exchange resin

Características físico-químicas dos vinhos obtidos a partir de mostos tratados com resina de troca catiônica

\begin{tabular}{|c|c|c|c|c|c|}
\hline Analytical parameters & $\begin{array}{c}\text { Effect of cation } \\
\text { exchange } \\
\text { treatment }\end{array}$ & $\begin{array}{c}\text { ST } \\
(\mathrm{pH} \mathrm{3.15)}\end{array}$ & $\begin{array}{c}\text { TR1 } \\
(\mathrm{pH} \mathrm{3.08)}\end{array}$ & $\begin{array}{c}\text { TR2 } \\
(\mathrm{pH} \mathrm{3.02)}\end{array}$ & $\begin{array}{c}\text { TR3 } \\
(\mathrm{pH} \mathrm{2.97)}\end{array}$ \\
\hline Volatile acidity (g/L) & n.s. & $0.35 \pm 0.09$ & $0.36 \pm 0.03$ & $0.36 \pm 0.02$ & $0.39 \pm 0.05$ \\
\hline Alcoholic strength (v/v \%) & n.s. & $10.23 \pm 0.08$ & $10.36 \pm 0.09$ & $10.37 \pm 0.09$ & $10.23 \pm 0.09$ \\
\hline Reducing substances (g/L) & n.s. & $1.48 \pm 0.07$ & $1.41 \pm 0.02$ & $1.38 \pm 0.02$ & $1.4 \pm 0.02$ \\
\hline Dry extract $(\mathrm{g} / \mathrm{L})$ & n.s. & $20.6 \pm 0.1$ & $20.5 \pm 0.1$ & $20.63 \pm 0.3$ & $20.9 \pm 0.4$ \\
\hline TP Index (A 280 nm) & n.s. & $4.42 \pm 0.07$ & $4.22 \pm 0.16$ & $4.16 \pm 0.02$ & $4.24 \pm 0.14$ \\
\hline Folin-Ciocalteau Index (mg/L) & n.s. & $147 \pm 12$ & $136 \pm 7$ & $133 \pm 6$ & $139 \pm 7$ \\
\hline Free SO2 (mg/L) & n.s. & $7.3 \pm ., 40$ & $7.4 \pm 0,51$ & $7.1 \pm 0.49$ & $7.2 \pm 0.14$ \\
\hline Combined SO2 (mg/L) & n.s. & $30.06 \pm 2.94$ & $33.8 \pm 3.96$ & $32.6 \pm 4.55$ & $35.63 \pm 7.28$ \\
\hline Total SO2 (mg/L) & n.s. & $37.36 \pm 2.54$ & $41.06 \pm 3.97$ & $40.06 \pm 4.18$ & $43.73 \pm 7.25$ \\
\hline pH & $* *$ & $3.15 \pm 0.01 \mathbf{a}$ & $3.08 \pm 0.01 \mathbf{b}$ & $3.02 \pm 0.01 \mathbf{c}$ & $2.97 \pm 0.01 \mathbf{d}$ \\
\hline Total acidity (g/L) & $* *$ & $9.1 \pm 0.1 \mathbf{~ d}$ & $9.4 \pm 0.1 \mathbf{c}$ & $9.8 \pm 0.1 \mathbf{b}$ & $10.4 \pm 0.1 \mathbf{a}$ \\
\hline Tartaric acid $(\mathrm{g} / \mathrm{L})$ & $*$ & $2.45 \pm 0.06 \mathbf{b}$ & $2.45 \pm 0.17 \mathbf{b}$ & $2.57 \pm 0.08 \mathbf{b}$ & $3.03 \pm 0.10 \mathrm{a}$ \\
\hline $\mathbf{L}^{*}$ & n.s. & $75.16 \pm 0.07$ & $75.39 \pm 0.09$ & $75.53 \pm 0.15$ & $75.55 \pm 0.12$ \\
\hline$a^{*}$ & n.s. & $-2.09 \pm 0.04$ & $-2.07 \pm 0.03$ & $-2.03 \pm 0.01$ & $-2.05 \pm 0.03$ \\
\hline $\mathbf{b}^{*}$ & $*$ & $6.3 \pm 0.2 \mathbf{a}$ & $5.6 \pm 0.2 \mathbf{b}$ & $5.2 \pm 0.4 \mathbf{b}$ & $5.2 \pm 0.1 \mathbf{b}$ \\
\hline$C^{*}$ & $*$ & $6.62 \pm 0.15 \mathbf{a}$ & $5.98 \pm 0.15 \mathbf{b}$ & $5.61 \pm 0.41 \mathbf{b}$ & $5.56 \pm 0.10 \mathbf{b}$ \\
\hline $\mathbf{h}^{*}$ & $*$ & $108.40 \pm 0.63 \mathbf{b}$ & $110.32 \pm 0.73 \mathbf{a b}$ & $111.33 \pm 1.44 \mathbf{a}$ & $111.65 \pm 0.65 \mathbf{a}$ \\
\hline A $420 \mathrm{~nm}$ & $* *$ & $0.086 \pm 0.006 \mathbf{a}$ & $0.074 \pm 0.002 \mathbf{b c}$ & $0.073 \pm 0.004 \mathbf{b c}$ & $0.070 \pm 0.003 \mathbf{c}$ \\
\hline
\end{tabular}

Mean values \pm standard deviation followed by different letters are significantly different according to the Tukey's test; n.s. non-significant; $*$ significant $(\mathrm{p}<0.05)$; ** very significant $(\mathrm{p}<0.01)$; Volatile Acidity (expressed as acetic acid); Total Acidity (expressed as tartaric acid); TP Index = Total Polyphenols Index (expressed as absorbance at $280 \mathrm{~nm}$ ); Folin-Ciocalteau Index (expressed in $\mathrm{mg} / \mathrm{L}$ of gallic acid). CIELab color $\left(\mathrm{L}^{*}=\right.$ lightness; $\mathrm{a}^{*}=$ green-red compound; $\mathrm{b}^{*}=$ blue-yellow compound; $\mathrm{C}^{*}=$ color chromaticity; $\mathrm{h}^{*}=$ hue angle); A $420 \mathrm{~nm}=$ absorbance at $420 \mathrm{~nm}$.

As observed in Table I, base wines obtained from the control and resin treated musts did not exhibit significant differences in volatile acidity, alcoholic content, reducing sugars, dry extract, and sulfur dioxide (SO2), indicating no influence of the cation exchange resin treatments on these parameters. Moreover, wines did not differ in their polyphenol content (Total Polyphenol Index and Folin-Ciocalteau Index), corroborating the results obtained by Bruijn et al. (2009) using ion exchange resins on white wines. Conversely, Mira et al. (2004), Cabrita et al. (2014), Lasanta et al. (2013), and Ibeas et al. (2015) reported a decrease in polyphenols, tannins, and/or anthocyanins of wines that had passed through ionic resins. Conflicting results may be associated with the use of different types of wines, resins and treatment intensity, but point out the need for additional studies to elucidate the effect of resins on polyphenols and assist winemakers' decisions. It is important to emphasize that in the present work, 'Chardonnay' must, the most important component of base wines for sparkling wines production, was used to evaluate the effect of cation exchange resins.

Color is one of the most important visual properties of wines and provides considerable information about their quality. Color is a visual sensation perceived from the refraction or reflection of light on the surface of objects. The evaluation of the chromatic characteristics of base wines obtained by the alcoholic fermentation of control and cationic resintreated musts are shown in Table I. The lightness $\left(\mathrm{L}^{*}\right)$ and $\mathrm{red} /$ green color component $\left(\mathrm{a}^{*}\right)$ were not significantly $(\mathrm{p} \geq 0.05)$ affected by resin treatments, and as expected, $a^{*}$ values were negatives, indicating a green tonality. Conversely, cationic resin treatments showed a significant decrease of blue/yellow color component $\left(\mathrm{b}^{*}\right)$, and chroma $\left(\mathrm{C}^{*}\right)$, and an increase of 
hue angle (h). The reduction of $b^{*}$ and $C^{*}$ values were directly related to $\mathrm{pH}$ reduction by must resin treatments, and on TR3 ( $\mathrm{pH} 2.97)$ wines reached 17.67 and $-16.01 \%$ of the control wine, respectively.

The decrease in yellow color intensity on resintreated derived wines was confirmed by absorbance at $420 \mathrm{~nm}$ (Table I). As $\mathrm{b}^{*}$ and $\mathrm{C}^{*}$ parameters, the reduction of yellow color intensity was proportional to $\mathrm{pH}$ reduction by the cationic resin treatments. These results differ from those obtained by Mira et al. (2006) that did not evidence important color modification after treatment of white wines with different cationic ion exchange resins but showed a color reduction in resin-treated red wines, attributing this finding to a decrease of total anthocyanins and phenol content. The evolution of wine color over nine months is presented in Figure 1. As can be observed, initial color intensity was proportional to the cationic resin treatment of musts. Moreover, wines obtained from TR3 must ( $\mathrm{pH}$ 2.97) showed lower color, compared with the control. This result corroborates that obtained by Benitez et al. (2002) that showed that resin-treated white wines exhibit a notably reduced susceptibility to browning. This phenomenon can be associated with the very slow phenol oxidation to quinones reactions at low $\mathrm{pH}$ and ion and copper depletion (Li et al., 2008; Oliveira et al., 2011).

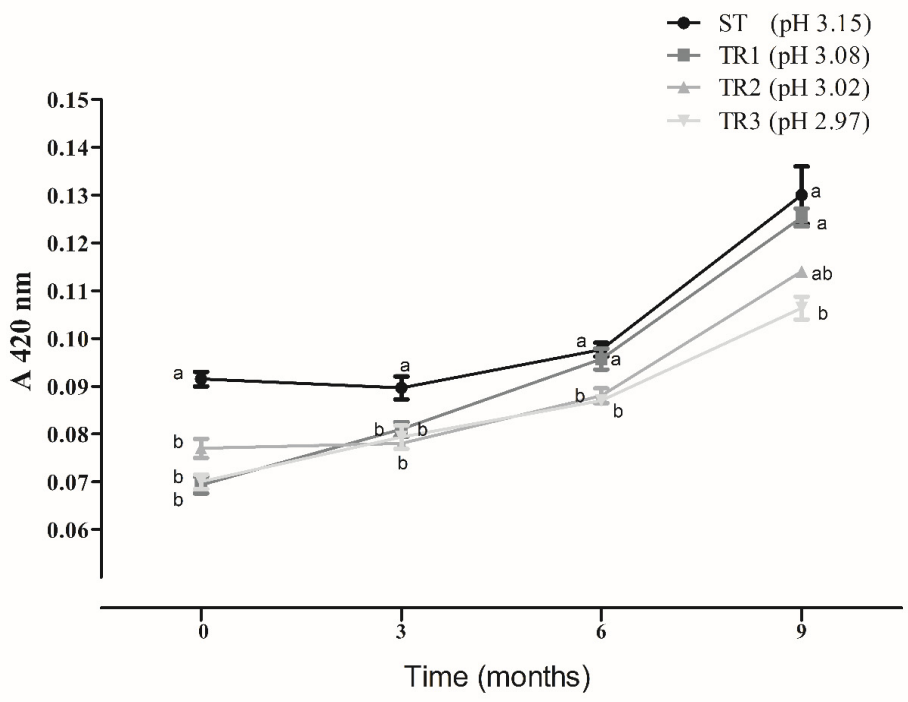

Figure 1. Evolution of the color (A $420 \mathrm{~nm}$ ) of wines obtained from control and cationic resin treated musts. Different letters at each time indicate significant differences by the Tukey's test $(\mathrm{p}<0.05)$. A $420 \mathrm{~nm}=$ absorbance at $420 \mathrm{~nm}$.

Evolução da cor (A 420nm) de vinhos obtidos a partir de mostos controle e tratados com resina cationica. Letras distintas em cada tempo indicam diferenças significativas pelo teste de Tukey $(p<0,05)$. A $420 \mathrm{~nm}=$ absorbância a $420 \mathrm{~nm}$.

Low $\mathrm{pH}$ affects microbial development and fermentation extending yeast lag phase, reducing fermentation rate, and increasing the acetic acid and glycerol concentrations (Liu et al., 2015). Moreover, $\mathrm{pH}$ stress can also affect enzymatic activities and the production and release of volatile compounds from sugar-bound aroma precursors and fermentative derived volatile compounds that contribute to wine aroma. Although not directly related to the present study, cationic resin-treated wines are perceived as less acidic than those treated by tartaric acid addition (Plane et al., 1980), but are generally considered as less colored and flavored than non-treated wines
(Zoecklin et al., 1995). This reduction of flavor and aroma has been attributed to the decrease in the concentration of several volatile compounds (Walker et al., 2002; Lasanta et al. 2013; Ibeas et al., 2015).

Table II shows the results of the analyses concerning the concentrations of the volatile compounds on wines obtained with resin-treated and control musts. Only three out of 18 compounds identified exhibited a significant difference between the control and the resin-treated samples. All these compounds are classified as acetate esters, and their sum showed a reduction dependent on the intensity of the resin treatments and the $\mathrm{pH}$ of the musts. 
TABLE II

Mean values of volatile compounds concentrations in the wines $\left(\mathrm{mg} \mathrm{L}^{-1}\right)$

Valores médios de concentração dos compostos voláteis nos vinhos ( $\mathrm{mg} \mathrm{L}^{-1}$ )

\begin{tabular}{|c|c|c|c|c|c|}
\hline Treatment & $\begin{array}{c}\text { Effect of cation } \\
\text { exchange } \\
\text { treatment }\end{array}$ & $\begin{array}{c}\mathbf{S T} \\
(\mathrm{pH} \mathrm{3.15)}\end{array}$ & $\begin{array}{c}\text { TR1 } \\
(\mathrm{pH} 3.08)\end{array}$ & $\begin{array}{c}\text { TR2 } \\
(\mathrm{pH} 3.02)\end{array}$ & $\begin{array}{c}\text { TR3 } \\
\text { (pH 2.97) }\end{array}$ \\
\hline \multicolumn{6}{|l|}{ LIGHT COMPOUNDS } \\
\hline Acetaldehyde & n.s. & $5.64 \pm 5.64$ & $4.40 \pm 4.40$ & $5.49 \pm 5.49$ & $4.10 \pm 4.10$ \\
\hline ALCOHOLS & & 159.29 & 166.13 & 169.35 & 167.01 \\
\hline 1-propanol & n.s. & $49.0 .3 \pm 6.59$ & $8.74 \pm 3.55$ & $46.0 \pm 7.00$ & $41.14 \pm 4.19$ \\
\hline 2-methyl-1-propanol & n.s. & $17.35 \pm 1.83$ & $18.96 \pm 1.15$ & $19.47 \pm 2.10$ & $19.94 \pm 1.83$ \\
\hline 2-methyl-1-butanol & n.s. & $16.82 \pm 1.14$ & $17.46 \pm 1.19$ & $18.58 \pm 0.91$ & $19.47 \pm 2.86$ \\
\hline 3-methyl-1-butanol & n.s. & $65.93 \pm 7.69$ & $70.90 \pm 5.24$ & $73.77 \pm 4.09$ & $73.67 \pm 8.90$ \\
\hline 2-phenylethanol & n.s. & $6.77 \pm 1.35$ & $6.91 \pm 1.51$ & $8.13 \pm 1.24$ & $9.36 \pm 4.04$ \\
\hline Hexanol & n.s. & $3.39 \pm 0.24$ & $3.16 \pm 0.15$ & $3.40 \pm 0.29$ & $3.42 \pm 0.62$ \\
\hline Cis-3-hexan-1-ol & & ND & ND & ND & ND \\
\hline Trans-3-hexen-1-ol & & ND & ND & ND & ND \\
\hline VOLATILE ACIDS & & 18.15 & 19.54 & 18.55 & 19.17 \\
\hline Octanoic Acid & n.s. & $8.62 \pm 0.83$ & $9.71 \pm 1.44$ & $8.90 \pm 1.93$ & $9.53 \pm 0.77$ \\
\hline Decanoic Acid & n.s. & $7.49 \pm 0.18$ & $7.52 \pm 0.39$ & $7.30 \pm 0.31$ & $7,37 \pm 0.21$ \\
\hline Dodecanoic Acid & n.s. & $2.03 \pm 0.29$ & $2.31 \pm 0.36$ & $2.36 \pm 0.74$ & $2.27 \pm 0.55$ \\
\hline Isobutyric acid & n.s. & ND & ND & ND & ND \\
\hline Butyric Acid & n.s. & ND & ND & ND & ND \\
\hline Hexanoic Acid & n.s. & ND & ND & ND & ND \\
\hline Isovaleric Acid & n.s. & ND & ND & ND & ND \\
\hline ACETATES & & 33.12 & 31.26 & 28.62 & 22.09 \\
\hline Ethyl Acetate & $* *$ & $27.06 \pm 2.77 \mathbf{a}$ & $26.01 \pm 1.84 \mathbf{a}$ & $23.66 \pm 1.70 \mathrm{a}$ & $19.98 \pm 2.17 \mathbf{b}$ \\
\hline Isoamyl Acetate & $* *$ & $1.39 \pm 0.26 \mathbf{a}$ & $0.75 \pm 0.20 \mathbf{b}$ & $0.51 \pm 0.34 \mathbf{b c}$ & $0.16 \pm 0.29 \mathbf{c}$ \\
\hline Hexyl Acetate & $* *$ & $2.45 \pm 0.19 \mathbf{a}$ & $2.49 \pm 0.10 \mathbf{a}$ & $2.34 \pm 0.20 \mathbf{a}$ & $0.01 \pm 0 \mathbf{b}$ \\
\hline Butyl Acetate & n.s. & $2.22 \pm 0.29$ & $2.01 \pm 0.11$ & $2.11 \pm 0.52$ & $1.94 \pm 0.23$ \\
\hline 2-phenylethyl Acetate & & ND & ND & ND & ND \\
\hline ETHYL ESTERS & & 8.10 & 7.65 & 7.47 & 7.60 \\
\hline Ethyl Hexanoate & n.s. & $1.99 \pm 0.08$ & $1.99 \pm 0.17$ & $1.97 \pm 0.08$ & $2.03 \pm 0.13$ \\
\hline Ethyl Octanoate & n.s. & $5.38 \pm 0.12$ & $5.33 \pm 0.25$ & $5.13 \pm 0.44$ & $5.16 \pm 0.22$ \\
\hline Ethyl Decanoate & n.s. & $0.73 \pm 0.49$ & $0.33 \pm 0.31$ & $0.38 \pm 0.39$ & $0.41 \pm 0.46$ \\
\hline Ethyl Dodecanoate & & ND & ND & ND & ND \\
\hline OTHER & & 7.17 & 6.74 & 7.15 & 6.40 \\
\hline Hexanal & n.s. & $2.05 \pm 0.50$ & $1.68 \pm 0.25$ & $1.54 \pm 0.29$ & $1.57 \pm 0.49$ \\
\hline Diethyl Succinate & n.s. & $5.12 \pm 0.94$ & $5.06 \pm 1.35$ & $5.61 \pm 1.69$ & $4.83 \pm 0.64$ \\
\hline
\end{tabular}

Mean values \pm standard deviation followed by different letters are significantly different according to the Tukey's test; n.s. - non-significant; ** very significant $(\mathrm{p}<0.01)$; ND $=$ Not Detected. 
Ethyl acetate showed a significant reduction of $26.2 \%$ in samples under TR3 and exhibited a linear decrease depending on the cationic resin treatment and $\mathrm{pH}$ of musts $(\mathrm{r}=0.949)$. Ethyl acetate accentuates varnish, nail polish, and somewhat fruity descriptors, and in excess can contribute negatively to wines (Lambrechts and Pretorius, 2000). The concentration of ethyl acetate varied from $27.06 \mathrm{mg} / \mathrm{L}$ (control) to $19.98 \mathrm{mg} / \mathrm{L}$ (TR3) all above its threshold $7.5 \mathrm{mg} / \mathrm{L}$ (Ferreira et al., 2000).

Isoamyl acetate showed the same behavior $(\mathrm{r}=0.988)$, but its concentration was significantly lower in all resin-treated wines compared to the control, with a reduction of $46.0 \%, 63.2 \%$, and $88.5 \%$, on TR1, TR2, and TR 3 treatments, respectively. This compound has banana and pear descriptors with an odor threshold of $0.03 \mathrm{mg} / \mathrm{L}$ (Ferreira et al., 2000). The observed differences in wines fell from $46.4 \mathrm{x}$ (control) to $5.3 \mathrm{x}$ (TR3) the odor threshold. Hexyl acetate concentration reduced only in the most drastic treatment (TR3), in which this compound was almost absent. This compound has perfume, green and floral descriptors with an odor threshold of $1.5 \mathrm{mg} / \mathrm{L}$ (Ferreira et al., 2000).

The acetates of higher alcohols are among the main responsible for the fermentation aromas of white wines and are synthesized by yeasts through the reaction of acetyl-CoA with alcohol catalyzed by alcohol acetyltransferases (Saerens et al., 2008). The lower concentration of acetates of higher alcohols of wines after cationic resin treatments might be explained by the removal of some cations that could have catalytic functions as enzymatic cofactors (Stehlik-Thomas et al., 2004). Moreover, Marais (1978) reported an important decrease of acetate esters concentration in wines obtained by the fermentation of acidified grape musts, indicating a possible impact of $\mathrm{pH}$ on the production, hydrolysis, and accumulation of this group of compounds. In this sense, it is important to emphasize that although not significant, higher alcohols concentration was higher on resin-treated wines, except for 1-propanol, and this increase was directly related to the intensity of resin treatment of grape musts, and inversely correlated with must $\mathrm{pH}$ and the corresponding acetates in wines.

Quantitative variations of aroma compounds have been reported in wines after ion exchange treatment (Benitez et al., 2002, Lasanta et al., 2013), but the results are conflicting. Benitez et al. (2002) reported a significant reduction of several aromatic compounds, among which acetates, while Lasanta et al. (2013) were able to identify just slight differences in a small number of volatile compounds. Some of these disagreements can be attributed to methodological differences, cationic resins and treatments, and $\mathrm{pH}$ dependent extraction of volatile compounds used in GC sample preparation. Independently of this, most of the work involving the treatment of wines with cationic resins evidenced a reduction of the aromatic characteristics of the wines (Benitez et al., 2002, Walker et al., 2002, Lasanta et al., 2013, Ibeas et al., 2015, Ponce et al., 2018).

Sensory analysis (Figure 2) showed low variations in color intensity, confirming the results obtained by CIELab and A $420 \mathrm{~nm}$. Bitter taste (bitterness), at gustatory analysis, showed no differences among the treated samples, whereas the acidity had significant differences. The sensation of acidity increased as in the chemical analyses, but only TR3 was statistically different from the ST.

At the aroma evaluation, the floral, citrus and herbaceous descriptors did not show statistical differences. In the case of the white fruit descriptor, the ST obtained the highest value and differed from all other treatments, which have not differed from each other. These results are in agreement with data found in the analyses of volatile compounds on which analytes such as isoamyl acetate, hexyl acetate and ethyl acetate, which are described as fruity and flowery, decreased as the treatments became more intense, coming to disappear in the case of hexyl acetate at TR3. The decrease of these compounds probably altered the perception of white fruits in the olfactory analysis.

As observed by Lasanta et al. (2013) testing red wines with cationic resin treatment having a $\mathrm{pH}$ value reduced from 3.8 to 3.5 and 3.3 , those wines with reduced $\mathrm{pH}$ received better evaluations. The scores for the intensity of taste and overall appreciation were also higher for wines with reduced $\mathrm{pH}$. However, the same results were found in the quality of the aroma, since the wines with cationic resin treatment were not the favorites. As analyzed in the present experiment, Lasanta et al. (2013) also observed a decrease of esters with fruity aromatic descriptors in the analyses performed.

At the sensory analysis performed by Ibeas et al. (2015) red wines treated with $\mathrm{pH}$ reduction (initial $\mathrm{pH}$ 3.55) that had a reduction of 0.03 presented no differences in relation to the control. However, those with a reduction of $0.1,0.16,0.19$ and 1.09 were evaluated negatively in comparison to the control. The evaluation criteria that had a negative impact on the perception of the judges were aromatic finesse, flavor intensity, body, balance, and persistence. 
trials where these samples were presented, wines treated with ion exchange resin received a lower rating. The sensory analysis performed in wines treated with ion exchange suggests that flavor and aroma are impacted by the treatment. The reduction of the aromatic intensity and certain aromas described as fruity should be taken into account as in this study, as well as in other related ones, this aspect was better evaluated in the control wines in both white wines and red wines.

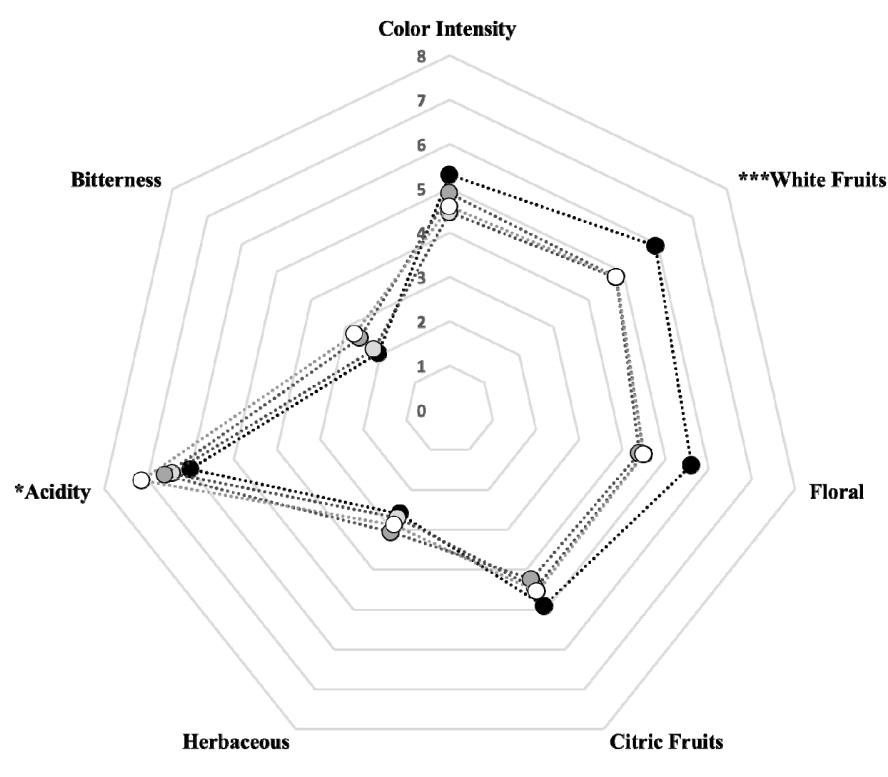

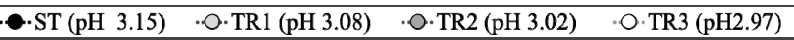

Figure 2. Sensory Analysis - Comparison of the means of the wine's attributes found by Quantitative Descriptive Analysis - QDA. *** Values are significantly different ( $\mathrm{p} \leq 0.05$, Tukey test) between ST and treatments TR1, TR2 and TR3. * Values are significantly different ( $\leq \leq 0.05$, Tukey test) between ST and TR3 treatment.

Análise Sensorial - Comparação das médias dos atributos dos vinhos encontrados pela Análise Descritiva Quantitativa - ADQ. *** Os valores do $S T$ são significativamente diferentes ( $p \leq 0,05$, teste de Tukey) dos tratamentos TR1, TR2 e TR3. * Os valores do ST são significativamente diferentes ( $p \leq 0,05$, teste de Tukey) do tratamento TR3.

\section{CONCLUSIONS}

The increase in the concentration of total acidity in wines with ionic resin treatment was in accordance with the treatment proposal. The analyses for alcohol strength, sugars, volatile acidity, dry extract, and total polyphenols returned no significant differences in the levels tested, which show that treatments with ion exchange resins for the grape must have no influences on such indicators. Wines from resin-treated musts had lower yellow color intensity indices than the control treatment, indicating greater oxidation stability than the standard treatment.

The cationic resin treated must derived wines exhibited a significative decrease in ethyl acetate, isoamyl acetate, and hexyl acetate concentration, directly proportional to $\mathrm{pH}$ reduction by resin treatment. Moreover, the reduction of these compounds influenced the olfactory perception in the sensory analysis, mainly in the grape must treatment to reduce the $\mathrm{pH}$ value by 0.18 . The increase of acidity through the resin influenced the taste analysis by changing the same $\mathrm{pH}$ value of 0.18 .

In general, moderate treatments (reduction of the $\mathrm{pH}$ value up to 0.13 ) led to minor changes in the concentration of volatile compounds and in the quantitative differences found in the sensory analysis, maintaining the advantage of increasing the acidity and color stability of the wine due to $\mathrm{pH}$ reduction. 


\section{ACKNOWLEDGMENTS}

The authors would like to thank IFRS (Federal Institute of Education, Science and Technology of Rio Grande do Sul - Bento Gonçalves Campus), UCS (University of Caxias do Sul), Ben-hur Rigoni and AEB Bioquímica Latino-Americana SA for yielding the resin samples for the experiment.

\section{REFERENCES}

ABNT NBR ISO 13299. 2017. Sensory analysis - Methodology - General guidance for establishing a sensory profile. $50 \mathrm{p}$. Associação Brasileira de Normas Técnicas, Brasília.

AEB-Group, 2013. pH STAB: Ion exchange resin. Technical information. Available at: http://www.acenologia.com/aeb/pdf/ph_stab.pdf (accessed on 20.07.2019).

AOAC, 1995. Official methods of analysis. 16.ed., 1094 p. AOAC, Washington.

Bailetti L.I., Santini C., Supino S., 2019. Sensory sciences and competitiveness in the wine business. In: Case Studies in the Wine Industry. 75-85. Woodhead Publishing, Duxford, UK.

Benitez P., Castro R., Barroso C.G., 2002. Removal of iron, copper and manganese from white wines through ion exchange techniques: effects on their organoleptic characteristics and susceptibility to browning. Anal. Chim. Acta., 458, 197-202.

Blouin J., Peynaud E., 2006. Enología Práctica: Conocimiento y elaboración del vino, 4 ed., 360 p. Mundi- Prensa, Madrid.

Bruijn J., Valdebenito A., Loyola C., Serra I., Salazar F., López F., 2009. Continuous stabilization of chardonnay with ion-exchange resin: influence on protein and phenolic profiles of wine. Chilean J.A.R., 69, 54-59.

Cabrita M.J., Clemente A., di Mari A., Couto M., Catarino S., 2014. A utilização de resinas de troca iônica em vinhos. Winetech plus, 3, 47-49.

Dutcosky S.D., 2007. Análise sensorial de alimentos. $2^{\mathrm{a}}$ ed. 540 p. Champagnat, Curitiba.

Edwards T., Singleton V., Boulton R., 1985. Formation of ethyl acids of tartaric acid during wine aging: Chemical and sensory effects. Am. J. Enol. Vitic., 36, 118-124.

Ferreira V., López R., Cacho J., 2000. Quantitative determination of the odorants of young red wines from different grape varieties. $J$. Sci. Food. Agric., 80, 1659-1667.

Gómez-Benítez J., Palacios Macías V.M., Pérez Rodríguez L., 2002. Estimación de los costes directos de la estabilización tartárica mediante tratamiento por frío, intercambio protónico $\mathrm{y}$ electrodiálisis. Tecn. del vino, July/August, 45-49.

Ibeas V., Correia A.C., Jordão A.M., 2015. Wine tartrate stabilization by different levels of cation exchange resin treatments: impact on chemical composition, phenolic profile and organoleptic properties of red wines. Food Res. Inter., 69, 364-372.

Lambrechts M.G., Pretorius I.S., 2000. Yeast its Importance to Wine Aroma: Review. S. Afr. J. Enol. Vitic., 21, 97-129.

Lasanta C. Caro I., Pérez L., 2013. The influence of cation exchange treatment on the final characteristics of red wines. Food Chem., 138, 1072-1078.
Li H., Anque G., Wang H., 2008. Mechanisms of oxidative browning of wine. Food Chem., 108, 1-13.

Liu X., Jia B., Sun X., Ai J., Wang L., Wang C., Zhao F., Zhan J., Huang W., 2015. Effect of initial PH on growth characteristics and fermentation properties of Saccharomyces cerevisiae. J. Food Sci., 80, 800-808.

Marais J., 1978. The effect of $\mathrm{pH}$ on esters and quality of Colombar wine during maturation. Vitis-Berichte Reben. Dokum. Weinb., 17, 396-403.

MAPA, 2013. Manual e métodos de análises de bebidas e vinagres. 2 p. MET BEB/003/001. Brasil.

Mira H., Leite P., Da Silva J.M.R., García A.S.C., 2004. Resinas permutadoras de iones para estabilização tartárica de vinhos. Enologia, 44, 15-24.

Mira H., Leite P., Da Silva J.M.R., Curvelo García A.S., 2006. Use of ion exchange resins for tartrate wine stabilization. J. Int. Sci. Vigne Vin, 40, 223-246.

Moreno J., Peinado R., 2012. Enological chemistry. 430 p. Academic Press, San Diego.

Murray J.M., Delahunty C.M., Baxter I.A., 2001. Descriptive sensory analysis: past, present and future. Food Res. Inter., 34, 461-471.

OIV, 2018. Compendium of International Methods of Wine and Must Analysis, Vol. 2, 837 p. OIV, Paris.

Oliveira C.M., Ferreira A.C.S., De Freitas V., Silva A.M.S., 2011 Oxidation mechanisms occurring in wines. Food Res. Int., 44, $1115-1126$

Palacios V.M., Caro I., Pérez L., 2001. Application of ion exchange techniques to industrial process of metal ions removal from wine. Adso., 7, 131-138.

Patrianakou M., Roussis I.G., 2013. Decrease of wine volatile aroma esters by oxidation. S. Afr. J. Enol. Vitic., 34, 241-245.

Plane R.A., Mattick L.R., Weirs L.D., 1980. An acidity index for the taste of wine. Am. J. Enol. Vitic., 31, 265-268.

Ponce F., Mirabal-Gallardo Y., Versari A., Felipe Laurie V., 2018 The use of cation exchange resins in wines: Effects on $\mathrm{pH}$, tartrate stability, and metal content. Cien. Inv. Agr., 45, 82-92.

Portaria $\mathrm{n}^{\mathrm{o}} 76 / 1986$, de 26 de novembro de 1986. Dispõe sobre os métodos analíticos de bebidas e vinagre: acidez total ou titulável, método 05. Diário Oficial da União, Brasília.

Ribéreau-Gayon P., Glories Y., Maujean A., Dubourdieu D., 2007. Trattato di enologia II: Chimica del vino Stabilizzazione Trattamenti 3 ed. 502 p. Edagricole Italia, Bologna.

Rockenbach I.I., Silva G.L.D., Rodrigues E., Kuskoski E.M., Fet R., 2008. Solvent influence on total polyphenol content, anthocyanins, and antioxidant activity of grape (Vitis vinifera) bagasse extracts from Tannat and Ancelota-different varieties of Vitis vinifera varieties. Food Sci. and Tech., 28, 238-244.

Saerens S., Delvaux F., Verstrepen K., Van Dijck P., Thevelein J., Delvaux F., 2008. Parameters affecting ethyl ester production by Saccharomyces cerevisiae during fermentation. Appli. Envi. Micro., 74, 454-461.

Stehlik-Tomas V., Grba S., Stanzer D., Vahcic N., Gulan Zetic V., 2003. Uptake of iron by yeast cells and its impact on biomass production. Acta Alim., 32, 279-287.

Tamasi G., Pardini A., Bonechi C., Donati A., Casolaro M., Leone G., Consumi M., Cini R., Magnani A., Rossi C., 2018. Ionic 
exchange resins and hydrogels for capturing metal ions in selected sweet dessert wines. Molecules., 23, 2973.

Togores J.H., 2018. Tratado de Enología $3^{\text {a }}$ ed. 1936 p. MundiPrensa, Madrid.

Walker G.M., 2004. Metals in yeast fermentation processes. $A d v$. Appl. Microb., 54, 197-230.

Walker T., Morris J., Threlfall R., Main G., 2002. pH modification of Cynthiana wine using cationic exchange. J. Agric. Food Chem., 50, 6346-6352.
Webber V., Dutra V. S., Spinelli F.R., Marcon A.R., Carnieli G.J. Vanderlinde R., 2014. Effect of glutathione addition in splarkling wine. Food Chem., 159, 391-398.

Zoecklin B.W., Fugelsang K.C., Gump B.H., Nury F.S., 1995. Laboratory procedures. In: Wine analysis and production. 493-497. Chapman \& Hall, New York. 